\title{
Should physicians be afraid of tort claims? Reviewing the empirical evidence
}

Citation for published version (APA):

van Dijck, G. (2015). Should physicians be afraid of tort claims? Reviewing the empirical evidence. Journal of European Tort Law, 2015(6), 282-303. https://doi.org/10.1515/JETL-2015-0017

Document status and date:

Published: 01/01/2015

DOI:

10.1515/JETL-2015-0017

Document Version:

Accepted author manuscript (Peer reviewed / editorial board version)

\section{Please check the document version of this publication:}

- A submitted manuscript is the version of the article upon submission and before peer-review. There can be important differences between the submitted version and the official published version of record.

People interested in the research are advised to contact the author for the final version of the publication, or visit the DOI to the publisher's website.

- The final author version and the galley proof are versions of the publication after peer review.

- The final published version features the final layout of the paper including the volume, issue and page numbers.

Link to publication

\footnotetext{
General rights rights.

- You may freely distribute the URL identifying the publication in the public portal. please follow below link for the End User Agreement:

www.umlib.nl/taverne-license

Take down policy

If you believe that this document breaches copyright please contact us at:

repository@maastrichtuniversity.nl

providing details and we will investigate your claim.
}

Copyright and moral rights for the publications made accessible in the public portal are retained by the authors and/or other copyright owners and it is a condition of accessing publications that users recognise and abide by the legal requirements associated with these

- Users may download and print one copy of any publication from the public portal for the purpose of private study or research.

- You may not further distribute the material or use it for any profit-making activity or commercial gain

If the publication is distributed under the terms of Article $25 \mathrm{fa}$ of the Dutch Copyright Act, indicated by the "Taverne" license above, 
(Published in Journal of European Tort Law. Volume 2015, Issue 6, Pages 282-303, ISSN (Online) 1868-9620, ISSN (Print) 1868-9612, DOI: 10.1515/jetl-2015-0017, January 2016)

\title{
Articles \\ Gijs van Dijck \\ Should Physicians be Afraid of Tort Claims? Reviewing the Empirical Evidence
}

\begin{abstract}
Do tort claims, or the fear of them, result in the adoption of practices aimed at protecting against tortious liability? Legislators, courts, and legal scholars often seem to think so, but is there empirical evidence to support this assumption? This article provides an answer to this question for the field of medical practice. An analysis of empirical studies on defensive medicine raises doubts as to whether the assumption holds true. The findings indicate that the empirical evidence is weak and that, if there is a concern about defensive practices, it seems to exist primarily in physicians' minds. The results contribute to a better understanding of how tort law works, what effects it has on behaviour, and whether legal actors, especially at the intersection of law and medicine, should give credence to the defensive practices concern.
\end{abstract}

Gijs van Dijck: Associate Professor, Tilburg Law School, the Netherlands, Email: G.vanDijck@uvt.nl

\section{Introduction}

\section{A Context: on the defensive Practices concern in general}

The fear of tort liability may cause a wide variety of actors - volunteers, the police, firemen, physicians et cetera - to change their behaviour, care levels, or beliefs. As will be demonstrated below, the defensive practices concern that arises from this phenomenon is frequently used by legislators and courts to advocate protection against tortious liability, sometimes even immunity. 
Protection against tortious liability can be observed at the level of fault and at the level of damages. Damages caps and limits on the circle of beneficiaries able to claim damages are examples of liability protection at the damages level. As regards liability protection at the fault stage, De Geest has found that, while full immunity is uncommon, many jurisdictions have gross negligence provisions to protect, for example, judges against tortious liability, including Belgium (clear violation of rules), France (faute lourde), Italy (gross negligence, but immunity for interpretation of the law and evaluation of facts) and Japan (obvious errors); in the US, there is full immunity regarding the performance of judicial tasks. ${ }^{1}$

In the US, statutes and case law also protect the police (only liable if they 'violate clearly established statutory or constitutional rights of which a reasonable person would have known'), ${ }^{2}$ firefighters (protection for actions and decisions that do not qualify as gross negligence), ${ }^{3}$ and volunteers (protection, although the type and extent of protection varies by state and statute). ${ }^{4}$ Similar protection can be observed in various European countries. Tort liability protection is applied to agencies that regulate and supervise the financial markets, ${ }^{5}$ to children, ${ }^{6}$ judges, company directors, employees, and various others.

G De Geest, Who Should Be Immune from Tort Liability? (2012) 41 Journal of Legal Studies (JLS) 291.

Harlow v Fitzgerald, 457 United States Supreme Court Reports (US) 800, 818 (1982).

De Geest (2012) 41 JLS 291 (providing examples and further references).

4 JR Horwitz/J Mead, Letting Good Deeds Go Unpunished: Volunteer Immunity Laws and Tort Deterrence (2009) 6 Journal of Empirical Legal Studies (JELS) 585.

$5 \quad$ For an overview, see RJ Dijkstra, Liability of Financial Supervisory Authorities in the European Union (2012) 3 Journal of European Tort Law (JETL) 346, 366 (providing further references and finding that, after analysing the vast majority of EU member states, negligence is the commonly used liability rule, followed by no-fault, gross negligence, bad faith, and immunity); RJ Dijkstra, Liability of financial regulators: Defensive conduct or careful supervision? (2009) 10 Journal of Banking Regulation (JBR) 269, $269 \mathrm{f}$ (stating that Denmark, Finland, France and Hungary apply normal liability rules to their financial regulators, that the United Kingdom, Ireland and Estonia have statutory immunities, and that other jurisdictions do not have a specific and targeted duty of care (due to concepts of 'proximity' or 'relativity') preventing regulators from being held liable). For the UK, see also Schedule 1ZA, para 25(3) of the Financial Services and Markets Act 2000, as inserted by the Financial Services Act 2012; Three Rivers District Council v Governor and Company of The Bank of England [2003] 2 Appeal Cases (AC) 1 (requiring misfeasance in a public office). For France, see also $M$ Andenas/D Fairgrieve, Misfeasance in Public Office, Government Liability, and European Influences (2002) 51 International Comparative Law Quarterly (ICLQ) 183 (describing the faute lourde that is required to establish liability in France). For the Netherlands, see art 1:25d of the 2012 Dutch Act of the Financial Supervision (Wet op het financieel toezicht) (requiring intentional harm/gross negligence or 'opzettelijk onbehoorlijke taakuitoefening... een opzettelijk onbehoorlijke uitoefening van bevoegdheden... grove schuld').

In the Netherlands, parents are liable for their children's actions and inactions until the child is 14 years old: see art 6:169 Dutch Civil Code (Burgerlijk Wetboek). If children are 14 years or older, fault liability applies, although parents can be liable as well if they were at fault and the child was 14 or 15 years old at the time of the wrong. In Belgium and France, the parents can be held liable for torts their children committed. There, the legislator shifted the burden of proof to the parents, entailing that they have to prove they could not have prevented the wrong: see art 1384 Belgium Civil Code (Burgerlijk Wetboek/Code Civil) and art 1384 French Civil Code (Code Civil). 
A variety of arguments have been used in favour of protection from tortious liability. Arguments include the weak position of one of the parties (eg children), legal certainty (eg limiting the circle of beneficiaries), and consistency with other jurisdictions (eg liability for regulators of the financial markets). ${ }^{7}$ Another important reason that is often mentioned to justify tort liability protection concerns the possible detrimental effects that tort liability can have on the behaviour of individuals and organizations. ${ }^{8}$ For example, it has been claimed that liability has or would have a chilling effect on financial regulators, implying that regulators would spend time and resources at preventing or reducing liability. ${ }^{9}$ This was also one of the reasons to introduce tort liability protection in the 2012 legislation for financial regulators (that is, the so-called AFM, DNB) in the Netherlands. ${ }^{10}$ A similar reasoning can be found in the UK. ${ }^{11}$

Not only legislators, but also courts have used the defensive practices concern to justify their decisions. For example, in England the House of Lords stated that liability might lead the police to execute their tasks with a detrimentally defensive frame of mind in a case where the plaintiff claimed damages from the police. In this case, the plaintiff argued that the police should have apprehended the suspect of her 20-year-old daughter who was attacked and murdered, because the suspect was already suspected of murders and attempted murders against similar victims and in similar circumstances. The plaintiff's claim was ultimately rejected on the basis (inter alia) that it would not be fair, just and reasonable to recognise a duty of care in respect of the police's investigation of crime ('investigative immunity'). ${ }^{12}$ In a different case, a suspect filed a claim because he was held without bail for 22 days after the prosecution learned that the suspect's semen sample did not match the one found on the victim. The court again rejected the suspect's claim, stating that the imposition of a duty of care would lead to defensive practices and that the prosecution would be 'constantly enmeshed in an avalanche of interlocutory civil proceedings and civil trials'. ${ }^{13}$ In contrast, the defensive practices concern was not considered as a decisive or even valid argument in several other instances. For example, in a case where the firemen deliberately turned off the sprinklers during a fire, the court held that liability is unlikely

7 AJ Verheij, Immuniteiten in het burgerlijk recht: handhaven of aanpassen?, in: N Juristen-Vereniging (ed), Immuniteiten Het recht opzij gezet? (2013) $83 \mathrm{f}$.

8 Ibid 84 (providing an overview).

9 Dijkstra (2009) 10 JBR 269, 270.

10 Kamerstukken II 2011-2012, 33 058, no 3 (Memorie van Toelichting). See also Kamerstukken II 2009-2010, 31 980, no 3-4, 24.

11 A Page, Regulating the Regulator - A Lawyer's Perspective on Accountability and Control, in: E Ferran/CAE Goodhart (eds), Regulating Financial Services and Markets in the Twenty First Century (2001) 145 (referring to defensive supervision as a reason for tort immunity).

12 Hill $v$ Chief Constable of West Yorkshire [1989] AC 53 (HL). See also, more recently, Michael v Chief Constable of South Wales [2015] United Kingdom Supreme Court (UKSC) 2 [2015] 2 Weekly Law Reports (WLR) 343.

13 Elguzouli-Dafv Commissioner of Police [1995] Queen's Bench (QB) 335. 
to influence the split second decisions firemen have to make. ${ }^{14}$ In general, the role of welfare considerations depends on the country as well as on the type of court: the role has been found to be minor at courts of first instance and intermediate appellate levels compared to courts at the ultimate appellate level. ${ }^{15}$

Even though there is a widespread belief within the legal community that tort liability causes individuals and organisations to display behaviour that is aimed at reducing or preventing liability rather than what they normally do or should do (for example, volunteer work, police work, fire extinguishing, treating patients), some have argued that the claim that tort law exposure actually has such detrimental effects is not supported by empirical evidence. ${ }^{16}$ Although interesting, the problem with such claims is that the evidence the authors refer to is always selective: it only contains an extremely small proportion of the empirical studies that are available, if they refer to any empirical studies at all, and methodological constraints of the studies are not discussed, at least not in doctrinal debates.

\section{B Research question}

This article analyses the defensive practices concern. Here, the defensive practices concern is defined as the concern that tort liability exposure results in adopting different practices aimed at preventing tort liability or at protecting oneself against it (hereafter: 'defensive practices hypothesis' or 'defensive practices concern'). The effect of defensive practices can be desirable to a certain extent (for example, more safety, better health care), but it becomes undesirable when it causes over-deterrence, for example if it results in more activities than necessary (such as more medical tests than what is medically indicated) or in avoiding conducting certain procedures (for instance referring risky patients).

This article seeks to remedy the current lack of knowledge in the legal field, amongst legal scholars in particular, regarding the possible detrimental impact of liability on behaviour. It seeks to answer the question whether empirical research supports the concern that a tort claim, or the fear for one, results in adopting practices aimed at protecting oneself against tort liability. This

14 Capital \& Counties plc Hampshire CC [1997] QB 1004, at $1043 \mathrm{f}$.

15 A Robertson, Policy-Based Reasoning in Duty of Care Cases (2013) 33 Legal Studies 119 (analysing and comparing 35 cases from England and Northern Ireland and 57 from Canada). See, however, I Griss, How Judges Think: Judicial Reasoning in Tort Cases from a Comparative Perspective (2013) 4 JETL 247 (claiming that case outcomes do not really differ among countries, despite differences in styles of reasoning).

16 For example, B Markesinis, Judicial Style and Judicial Reasoning in England and Germany [2000] Cambridge Law Journal (CLJ) 294, 303 (claiming that the evidence remains slim, referring to a 1996 US study); J Wright, Local Authorities, the Duty of Care and the European Convention on Human Rights (1998) 18 Oxford Journal of Legal Studies (OJLS) 1, 3, 10 (claiming that the defensive practices concern is a hypothesis rather than a proven conclusion, and that it is not supported by empirical evidence). 
article focuses on the medical field and, consequently, on empirical studies on medical malpractice. Medical malpractice has been considered a societal problem in various jurisdictions. ${ }^{17}$ The fact that researchers have produced a relatively large number of empirical studies on this topic ${ }^{18}$ allows for evaluating whether the outcomes of these studies point into a similar direction and, if not, whether differences in outcomes are the results of methodological issues.

The insights presented in this article are relevant for several reasons. A systematic review of empirical defensive medicine studies contributes to a better understanding of whether tort liability has an effect on physicians' views and actions. This is not only relevant for the medical field, but also for policy makers, courts and for tort law in general, considering the lack of knowledge amongst legal scholars and policymakers regarding whether tort law impacts on behaviour. Furthermore, a discussion of the methodology deployed in the various studies helps identifying how differently defensive practices can be defined, tested, and analysed. Such insights are helpful in determining which defensive medicine studies are of the best quality, which is of importance to researchers and policy makers who evaluate existing research or aim to test the defensive practices concern.

\section{Approach}

The conclusions are based on an assessment of empirical studies that examine the relationship between medical malpractice liability and defensive practices. Scanning reviews for empirical defensive medicine studies ${ }^{19}$ and an additional $\operatorname{search}^{20}$ resulted in the empirical studies that are

17 BS Black et al, Stability, Not Crisis: Medical Malpractice Claim Outcomes in Texas, 1988-2002 (2005) 2 JELS 207 (discussing, while providing further references, the issue of malpractice payments allegedly increasing insurance rates in the US, and, in contrast, finding stable malpractice claims and payments over time). $M P a i k / B S$ Black/DA Hyman, The Receding Tide of Medical Malpractice Litigation Part 1: National Trends (2013) 10 JELS 612 (finding declining rates for per-physician rate of paid medical malpractice claims between 1992 and 2012 , for law suit rates, and for payout per physician). For Australia, see eg T Drabsch, Medical negligence: an update. Briefing paper 2/2004 to the Parliament of NSW (2004) (describing (1) the rise of insurance premiums in Australia allegedly caused by an increase in medical litigation, and (2) how the government responded to the crisis).

18 Of course, empirical studies in different fields are available. See eg DJ Givelber/WJ Bowers/CJ Blitch, Tarasoff, Myth and Reality: An Empirical Study of Private Law in Action (1984) Wisconsin Law Review (WLR) 443 (psychiatrists), J Hartshorne/N Smith/R Everton, 'Caparo Under Fire': A Study into the Effects upon the Fire Service of Liability in Negligence (2000) 63 Modern Law Review (MLR) 502 (firemen), and Horwitz and Mead (2009) 6 JELS 585 (volunteers).

19 For example, MM Mello, Medical Malpractice: Impact of the Crisis and Effect of State Tort Reforms (Research Synthesis Report 10, 2006); T Eisenberg, The Empirical Effects of Tort Reform, in: JH Arlen (ed), Research Handbook on the Economics of Torts (2013); K Zeiler/L Hardcastle, Do Damages Caps Reduce Medical Malpractice Insurance Premiums?: A Systematic Review of Estimates and the Methods Used to Produce Them, in: JH Arlen (ed), Research Handbook on the Economics of Torts (2013). Reference tracking was used to increase the number of studies.

Recent studies were identified through content alerts in combination with reference tracking of these and previous studies. 
referred to in the rest of this article. As it turns out, the majority of the defensive medicine studies are conducted in the United States, partly because in the US more databases are available for research purposes. ${ }^{21}$ In this article, the US serves as an interesting point of reference. If an effect of tort liability were to be expected somewhere, it would be in the US, since the US is often perceived to be more litigious compared to most other countries. Conversely, if no or very small effects are observed in the US, it seems improbable that stronger effects would be found in other countries or jurisdictions.

This article will not address the statistical techniques used in empirical defensive medicine studies. One encounters a variety of statistical techniques deployed by defensive medicine researchers, ${ }^{22}$ ranging from fixed-effects regression models to hierarchical (multi-level) models to techniques that include instrumental variables. The type of statistical analysis may influence whether a researcher finds an effect. For instance, it is not certain whether liability effects increase or decrease over time. ${ }^{23}$ Zeiler and Hardcastle (2013), who found a wide variation in techniques used in studies that estimate the impact of caps on malpractice premiums, claim that it is difficult to determine whether studies that find effects are better or superior from a methodological perspective than studies that do not observe an effect. ${ }^{24}$ One methodological flaw can already produce inaccurate results, while most studies that examine the impact of tort reforms on malpractice premiums contain one or more flaws. ${ }^{25}$ Consequently, it is often difficult to evaluate a statistical technique, even though the decision to choose a certain technique can impact on the results.

This article is structured as follows. It starts with a discussion of the results of empirical defensive medicine studies (section II). Because the results are mixed, the analysis continues with a breakdown of the methodologies deployed in the various studies in order to narrow down the results (section III). The article concludes by answering the research question: should physicians fear tort liability (section IV)?

21 See eg the National Practitioner Data Bank (NPDB), which in 2013 reported that it contained all medical liability payments made on behalf of physicians, $<$ http://www.ama-assn.org/ama/pub/physician-resources/legaltopics/business-management-topics/national-practitioner-data-bank.page $>$ (accessed 15 February 2013. The NPDB can nowadays be used if one agrees to a Data Use Agreement, see $<$ http://www.npdb.hrsa.gov/resources/publicData.jsp $>$ ).

22 Zeiler/Hardcastle (fn 19).

23 Fixed-effect models may not adequately capture such time effects, which may result in inaccurate results because they are confounded by time effects. Random-effects models can be a solution to this problem, but those models have their own assumptions and limitations. See Yang et al (2008) 5 JELS 21, 27.

24 Zeiler/Hardcastle (fn 19).

25 Ibid. 


\section{Mixed results}

Eisenberg (2013) and Zeiler and Hardcastle (2013) collected, compared, and evaluated several empirical studies, some of which relate to defensive medicine. ${ }^{26}$ The Eisenberg publication concludes that empirical studies frequently find that particularly damage caps reduce malpractice insurance premiums. Zeiler and Hardcastle (2013), after a systematic analysis of 197 studies, find that only 49 results (25\%) support the claim that tort reforms result in lower malpractice insurance premiums. $^{27}$

Research has also examined the effect of tort reforms on patient safety (no effect), on the financial situation of hospitals (no effect), on health care spending (no or small effects), and on the number lawsuits and the damages that are awarded in those lawsuits (effects found in most studies). ${ }^{28}$ Studies that tested the effect of liability on physicians' practices provide mixed results: some studies that used tort reforms as a measure of the extent of liability risk (hereafter: measure of liability risk) find an effect of the reform on what physicians do, while most studies that used insurance premiums as a measure of malpractice pressure tend to find no relationship between malpractice premiums and claims. ${ }^{29}$ Mixed results have also been found for the effect of tort reforms on physician supply (that is, the number of physicians, where physicians locate, or the number of physicians that relocate). ${ }^{30}$ While some studies do not find that tort reform impacts on the number of physicians, other studies that used physician supply as measure of defensive medicine report relatively small effects (for example, the introduction of a tort reform associated with a $2 \%$ to $6 \%$ increase of the number of physicians). ${ }^{31}$

A recent publication in the New England Journal of Medicine examined the effect of US tort reforms on physician services for elderly patients (Medicare patients) in cases of emergency care. In this research, physician services were measured by means of changes in the use of

26 Eisenberg and Zeiler/Hardcastle (fn 19).

27 The authors selected those studies that reported statistically significant effects at the 5\% level.

28 Eisenberg (fn 19) (providing references to reviews and empirical studies). To similar effect, but not using tort reforms as a measure of liability risk, FA Sloan et al, Effects of the Threat of Medical Malpractice Litigation and Other Factors on Birth Outcomes (1995) 33 Medical Care (Med Care) 700 (finding 'no systematic improvement in birth outcomes in response to an increased threat of medical malpractice litigation was obtained' when surveying physicians).

29 Eisenberg (fn 19).

30 Ibid.

31 For example, K Baicker/A Chandra, Defensive Medicine and Disappearing Doctors? (2005) 28 Regulation 24; YT Yang et al, A Longitudinal Analysis of the Impact of Liability Pressure on the Supply of ObstetricianGynecologists (2008) 5 JELS 21; DL Sobel/KR Loughlin/CL Coogan, Medical Malpractice Liability in Clinical Urology: A Survey of Practicing Urologists (2006) 175 The Journal of Urology (J Urol) 1847; DP Kessler/WM Sage/DJ Becker, Impact of Malpractice Reforms on the Supply of Physician Services (2005) 293 The Journal of the American Medical Association (JAMA) 2618; J Klick/T Stratmann, Medical Malpractice Reform and Physicians in High-Risk Specialties (2007) 36 JLS 121; DA Matsa, Does Malpractice Liability Keep the Doctor Away? Evidence from Tort Reform Damage Caps (2007) 36 JLS 143. 
computed tomography (CT) or magnetic resonance imaging (MRI), per-visit emergency department charges, and the rate of hospital admissions. ${ }^{32}$ After comparing states that adopted a tort reform with neighbouring states that did not, the study finds that although 'there was a small reduction in charges in one of the three states (Georgia), our results in aggregate suggest that these strongly protective laws caused little (if any) change in practice intensity'. ${ }^{33}$ Additionally, recent studies confirm that damage caps reduce both claim rates and payout per claim. ${ }^{34}$

Tort reforms are obviously not the only way to capture the extent of liability risks. Several other variables have been used to measure liability risks and to examine whether these risks have an effect on physicians' behaviour. These studies also show mixed results as to whether liability results in defensive medicine (Table 1).

Table 1: Defensive Medicine Studies (not analysing tort reforms)

\begin{tabular}{|c|c|c|c|c|c|}
\hline Authors & Method & Medical Field & $\begin{array}{l}\text { Cause } \\
\text { (Independent } \\
\text { Variable) }\end{array}$ & $\begin{array}{l}\text { Effect (Dependent } \\
\text { Variable) }\end{array}$ & Results \\
\hline $\begin{array}{l}\text { Thomas et al } \\
(2010)^{35}\end{array}$ & Database(s) & Various & $\begin{array}{l}\text { Malpractice } \\
\text { premiums }\end{array}$ & Health care costs & $\begin{array}{l}\text { Significant } \\
\text { but small } \\
\text { effects }\end{array}$ \\
\hline $\mathrm{Xu}$ et al (2009) & Survey & $\begin{array}{l}\text { Obstetrics }+ \\
\text { family } \\
\text { physicians }\end{array}$ & $\begin{array}{l}\text { Malpractice } \\
\text { premiums }+ \\
\text { claims }\end{array}$ & Physician supply & $\begin{array}{l}\text { No } \\
\text { significant } \\
\text { effects }\end{array}$ \\
\hline Yang et al (2008) & Database(s) & Obstetrics & $\begin{array}{l}\text { Malpractice } \\
\text { premiums (+ } \\
\text { tort reforms) }\end{array}$ & Physician supply & $\begin{array}{l}\text { No } \\
\text { significant } \\
\text { effect }\end{array}$ \\
\hline Gius $(2000)^{38}$ & & & $\begin{array}{l}\text { Malpractice } \\
\text { premiums }\end{array}$ & Physician supply & $\begin{array}{l}\text { Significant, } \\
\text { negative }\end{array}$ \\
\hline
\end{tabular}

32 DA Waxman et al, The Effect of Malpractice Reform on Emergency Department Care (2014) 371 The New England Journal of Medicine (NEJM) 1518.

33 Waxman et al (2014) 371 NEJM 1523.

34 M Paik/BS Black/DA Hyman, The Receding Tide of Medical Malpractice Litigation Part 2: Effect of Damage Caps (2013) 10 JELS 639.

35 JW Thomas/EC Ziller/DA Thayer, Low Costs of Defensive Medicine, Small Savings from Tort Reform (2010) 29 Health Affairs (Health Aff) 1578.

36 X Xu et sl, Malpractice Burden, Rural Location, and Discontinuation of Obstetric Care: A Study of Obstetric Providers in Michigan (2009) 25 Journal of Rural Health (JRH) 33.

37 Yang et al (2008) 5 JELS 21.

38 MP Gius, Examination of the Determinants of Physician Supply at the State Level (2000) 6 Journal of Business and Economic Studies (JBES) 73, could not retrieve the study. Information is therefore based on Eisenberg (fn 19). 


\begin{tabular}{|c|c|c|c|c|c|}
\hline & & & & & effect \\
\hline $\begin{array}{l}\text { Grumbach et al } \\
(1997)^{39}\end{array}$ & Database(s) & Obstetrics & $\begin{array}{l}\text { Malpractice } \\
\text { premiums }\end{array}$ & Physician supply & $\begin{array}{l}\text { No } \\
\text { significant } \\
\text { effect }\end{array}$ \\
\hline $\begin{array}{l}\text { Baicker et al } \\
(2007)^{40}\end{array}$ & Databases(s) & $\begin{array}{l}\text { Various } \\
\text { (medicare } \\
\text { eligibles) }\end{array}$ & $\begin{array}{l}\text { Malpractice } \\
\text { premiums + } \\
\text { malpractice } \\
\text { payments }\end{array}$ & Physician services & $\begin{array}{l}\text { Effect of } \\
\text { payments, } \\
\text { but not of } \\
\text { premiums }\end{array}$ \\
\hline $\begin{array}{l}\text { Baicker/Chandra } \\
(2005)^{41}\end{array}$ & Database(s) & Obstetrics & $\begin{array}{l}\text { Malpractice } \\
\text { costs (including } \\
\text { premiums) }\end{array}$ & Physician services & $\begin{array}{l}\text { Little } \\
\text { evidence of } \\
\text { increased } \\
\text { use }\end{array}$ \\
\hline Dubay et al $(2001)^{42}$ & Database(s) & Obstetrics & $\begin{array}{l}\text { Malpractice } \\
\text { premiums }\end{array}$ & Physician services & $\begin{array}{l}\text { Small } \\
\text { significant } \\
\text { effect }\end{array}$ \\
\hline Dubay et al (1999) & Database(s) & Obstetrics & $\begin{array}{l}\text { Malpractice } \\
\text { premiums }\end{array}$ & Physician services & $\begin{array}{l}\text { Small } \\
\text { significant } \\
\text { effect }\end{array}$ \\
\hline $\begin{array}{l}\text { Dranove/Gron } \\
(2005)^{44}\end{array}$ & Database(s) & $\begin{array}{l}\text { Obstetrics, } \\
\text { neurology }\end{array}$ & Time (period) & Physician services & $\begin{array}{l}\text { Substantial } \\
\text { significant } \\
\text { effects }\end{array}$ \\
\hline $\begin{array}{l}\text { Kessler/McClellan } \\
(1997)^{45}\end{array}$ & $\begin{array}{l}\text { Database(s), } \\
\text { survey }\end{array}$ & Various & $\begin{array}{l}\text { Malpractice risk } \\
\text { (involvement in } \\
\text { previous claim) }\end{array}$ & Physician services & $\begin{array}{l}\text { Small to } \\
\text { medium } \\
\text { effects }^{46}\end{array}$ \\
\hline
\end{tabular}

39 K Grumbach et al, Charges for Obstetric Liability Insurance and Discontinuation of Obstetric Practice in New York (1997) 44 Journal of Family Practice (JFP) 61.

40 K Baicker/ES Fisher/A Chandra, Malpractice Liability Costs And The Practice Of Medicine In The Medicare Program (2007) 26 Health Aff 841.

${ }^{41}$ K Baicker/A Chandra, The Effect of Malpractice Liability on the Delivery of Health Care (2005) 8 Forum for Health Economics \& Policy (FHEP) 1.

42 L Dubay/R Kaestner/T Waidmann, Medical Malpractice Liability and its Effect on Prenatal Care Utilization and Infant Health (2001) 20 Journal of Health Economics (J Health Econ) 591.

43 L Dubay/R Kaestner/T Waidmann, The impact of malpractice fears on cesarean section rates (1999) $18 \mathrm{~J}$ Health Econ 491.

44 D Dranove/A Gron, Effects Of The Malpractice Crisis On Access To And Incidence Of High-Risk Procedures: Evidence From Florida (2005) 24 Health Aff 802.

45 DP Kessler/MB McClellan, Effects of Malpractice Pressure and Liability Reforms on Physicians' Perceptions of Medical Care (1997) 60 Law and Contemporary Problems (LCP) 81.

46 The study included several measures for 'liability' (eg involvement in previous claims, tort reforms, and perceived malpractice risk, and a combination) and for 'defensive practices' (eg practice patterns, changes in practices). The results 'suggest that law reforms affect physicians' attitudes, both by reducing the probability of 


\begin{tabular}{|c|c|c|c|c|c|}
\hline $\begin{array}{l}\text { Entman et al } \\
(1994)^{47}\end{array}$ & Database(s) & Obstetrics & $\begin{array}{l}\text { Malpractice risk } \\
\text { (claims history) }\end{array}$ & $\begin{array}{l}\text { Physician services' } \\
\text { quality }\end{array}$ & $\begin{array}{l}\text { No } \\
\text { significant } \\
\text { effect }\end{array}$ \\
\hline Mello et al (2004) & Survey & Various & Malpractice risk & $\begin{array}{l}\text { Professional } \\
\text { reactions/perceptions }\end{array}$ & $\begin{array}{l}\text { Decreasing } \\
\text { satisfaction } \\
\text { in ways that } \\
\text { may affect } \\
\text { the quality } \\
\text { of care }\end{array}$ \\
\hline Reed et al $(2008)^{49}$ & Survey & Various & Malpractice risk & Teaching behaviour & $\begin{array}{l}\text { Substantial } \\
\text { effects }(\mathrm{eg} \\
\text { rho }=0.38, \mathrm{p} \\
\quad<.001)\end{array}$ \\
\hline $\begin{array}{l}\text { Harvard Medical } \\
\text { Study }(1990)^{50}\end{array}$ & Survey & Various & Malpractice risk & Physician services & Mixed \\
\hline Brilla et al $(2006)^{51}$ & Survey & Neurology & $\begin{array}{l}\text { Malpractice risk } \\
\text { (country) }\end{array}$ & $\begin{array}{l}\text { Physician services }+ \\
\text { teaching behaviour }\end{array}$ & $\begin{array}{l}\text { Statistically } \\
\text { significant } \\
\text { differences }\end{array}$ \\
\hline Symon $(2000)^{52}$ & Survey & Obstetrics & $\begin{array}{l}\text { Malpractice } \\
\text { (country) }\end{array}$ & $\begin{array}{l}\text { Professional } \\
\text { reactions/perceptions } \\
\text { due to liability } \\
\text { concerns }\end{array}$ & $\begin{array}{l}\text { Substantial } \\
\text { differences } \\
\text { between } \\
\text { English and } \\
\text { Scottish } \\
\text { doctors }\end{array}$ \\
\hline $\begin{array}{l}\text { Martin et al } \\
(1991)^{53}\end{array}$ & Survey & Various & Malpractice risk & Stress & $\begin{array}{l}\text { Increased } \\
\text { stress if } \\
\text { cases were }\end{array}$ \\
\hline
\end{tabular}

an encounter with the liability system, and by changing the nature of the experience of being sued for those physicians who defend against malpractice claims': see ibid 105).

47 SS Entman et al, The Relationship Between Malpractice Claims History and Subsequent Obstetric Care (1994) 272 JAMA 1588.

48 MM Mello et al, Caring for Patients in a Malpractice Crisis: Physician Satisfaction and Quality of Care (2004) 23 Health Aff (Millwood) 42.

49 DA Reed et al, Do Fears of Malpractice Litigation Influence Teaching Behaviors? (2008) 20 Teaching and Learning in Medicine: An International Journal (Teach Learn Med) 205.

50 Harvard Medical Practice Study, Patients, Doctors, and Lawyers: Medical Injury, Malpractice Litigation, and Patient Compensation in New York (1990).

$51 \quad R$ Brilla et al, Are Neurology Residents in the United States being Taught Defensive Medicine? (2006) 108 Clinical Neurology and Neurosurgery (Clin Neurol Neurosurg) 374.

52 A Symon, Litigation and defensive clinical practice: quantifying the problem (2000) 16 Midwifery 8.

53 CA Martin et al, Physicians' Psychologic Reactions to Malpractice Litigation (1991) 84 South Medical Journal (SMJ) 1300. 


\begin{tabular}{|c|c|c|c|c|c|}
\hline & & & & & $\begin{array}{l}\text { pending or if } \\
\text { there were } \\
\text { multiple } \\
\text { suits }\end{array}$ \\
\hline $\begin{array}{l}\text { Levinson et al } \\
(1997)^{54}\end{array}$ & Database(s) & $\begin{array}{l}\text { General } \\
\text { internists, } \\
\text { family } \\
\text { practitioners, } \\
\text { orthopedic } \\
\text { surgeons }\end{array}$ & $\begin{array}{l}\text { Clinical } \\
\text { specialties }\end{array}$ & $\begin{array}{l}\text { Professional } \\
\text { reactions/perceptions }\end{array}$ & Mixed \\
\hline
\end{tabular}

Based on these studies, the general impression is that the results are mixed, that effects are more often found in survey research than in actual practice research (that is, research that is based on files or existing databases), and that the effects that are found seem to be larger in survey research than in actual practice research.

\section{Making sense of the results}

In an attempt to disentangle the results and to understand whether defensive medicine exists, the designs of the studies and the measures that were used were further inspected. It will be analysed whether the methodologically superior research designs provide evidence of the existence of defensive medicine.

\section{A Measures used in empirical studies}

Empirical research has used various measures to test whether tort liability has an effect on physician behaviour. Studies generally distinguish between negative defensive medicine and positive defensive medicine. ${ }^{56}$ Negative defensive medicine concerns situations where physicians no longer perform risky (but desirable) operations due to liability concerns, refer risky patients to other doctors, or stop seeing certain patients. Negative defensive medicine is therefore about the avoidance of certain medical procedures or interventions). Positive defensive medicine means

W Levinson et al, Physician-Patient Communication. The Relationship with Malpractice Claims among Primary Care Physicians and Surgeons (1997) 277 JAMA 553.

55

Eg BB Erus Malpractice Liability Crisis and Physician Location Choice (2004).

56 Thomas/Ziller/Thayer (2010) 29 Health Aff 1578; USC Office of Technology Assessment, Defensive Medicine and Medical Malpractice (1994) 1578; JR Ball, The Medical Malpractice Threat: A Study of Defensive Medicine (1971) Duke Law Journal (DLJ) 939, 942; EP Bernzweig, Defensive Medicine, in: Report of the Secretary's Commission on Medical Malpractice (1973) Appendix 38-40. 
that physicians take better care as a result of liability, for example by ordering more tests to prevent liability ('assurance'). Some level of avoidance and assurance behaviour is acceptable and can even be desirable. It is over-deterrence that is undesirable.

Certain measures stand out as popular measures to collect evidence for defensive medicine (that is, the dependent variable). A first popular measure of defensive medicine is physician supply. ${ }^{57}$ The idea behind choosing physician supply as a measure of defensive medicine is that it is a sign that tort liability has detrimental effects on physicians if they decide to start practising in 'liability-friendly' states, take early retirement, or if they relocate after they have been confronted with a claim or held liable, or where the probability of being confronted with a claim increases. However, physician supply also may not be a very reliable measure. Studies that adopted physician supply as a measure of defensive medicine have been criticised for that fact that changes in physician supply are not accurately reported in databases, and that trainees are not included in the databases, even though trainees are an important part of the physician population. ${ }^{58}$ Moreover, a drop in the number of physicians could be seen as a type of defensive medicine, but relocation is only one of the possible changes liability can have on a physician. Moving because of liability concerns seems a drastic measure for physicians, particularly if the physician has a family and social life in the area where he or she works. It does therefore not surprise that studies that use physician supply generally find no or small effects.

A second measure that is commonly used is physician services. Studies that use this measure test whether physicians make different medical decisions (for example, ordering different tests, following different procedures) after they have been confronted with a legal claim or when they have a higher probability of having a legal claim filed against them. Physician services can be used to test either positive defensive medicine or negative defensive medicine, but are often used to test the former. ${ }^{59}$

57 For example, Baicker/Chandra (2005) 8 FHEP 1 or (2005) 28 Regulation 24; Yang et al (2008) 5 JELS 21; Sobel/Loughlin/Coogan (2006) 175 J Urol 1847; Kessler/Sage/Becker (2005) 293 JAMA 2618; Klick/Stratmann (2007) 36 JLS s121; Matsa (2007) 36 JLS.

Yang et al (2008) 5 JELS 21 (providing further references).

59 For studies that focused on positive defensive medicine, see B Kim, The Impact of Malpractice Risk on the Use of Obstetrics Procedures (2007) 36 JLS 79 (using the number of C-sections, prenatal care visits, and diagnostic tests as dependent variables); Dubay/Kaestner/Waidmann (1999) 18 J Health Econ 491 (using the number of Csections as the dependent variable). See also DM Studdert et al, Defensive Medicine among High-Risk Specialist Physicians in a Volatile Malpractice Environment (2005) 293 JAMA 2609 (using measures of both positive and negative defensive medicine. The study used ordering more tests than medically indicated, prescribing more medications than medically indicated, referring to specialists in unnecessary circumstances, and suggesting invasive procedures against professional judgment as assurance measures (positive defensive medicine). The study used avoiding conducting certain procedures/interventions and avoiding caring for high-risk patients as measures for avoidance behaviour (negative defensive medicine)). 
Various more specific measures have been used to examine physician services. For example, research on obstetrics has included measures such as method of delivery, ${ }^{60}$ whether the onset of prenatal care was delayed, ${ }^{61}$ the number of prenatal care visits, ${ }^{62}$ and the range of prenatal resources employed. ${ }^{63}$ Physician services seem to be the measure that comes closest to what defensive medicine is about. Using physician services as a defensive practices measure is appealing, because it is a direct measure of the core activity of physicians: providing health care to patients. Consequently, the measure has more appeal than, for example, physician supply, which seems to be less closely related to providing health care to patients.

An examination of which independent variables are used in defensive medicine research reveals that tort reforms are a popular measure to analyse whether liability has an effect on physicians' behaviour. The rationale behind selecting tort reforms as a measure of liability risk is that comparing different liability regimes allows researchers to seek whether these differences are associated with changes in outcome by reference to measures such as physician supply ${ }^{64}$ and the types of procedures that physicians perform or the tests they order. ${ }^{65} \mathrm{~A}$ commonly used research technique is the 'difference-in-differences' approach whereby states in the US with and without liability protection (for example, damage caps) are compared, and a comparison is made between before and after the enactment of the tort reform.

The introduction of damages caps, where the damages are capped at a maximum amount, is the tort reform that is most frequently used in research. ${ }^{66}$ Other tort reforms that have been subject of investigation in a defensive medicine context are the joint and several liability rule (JSL, indicating that each defendant is liable for the entire amount of claimant's damages), and the collateral source rule reforms (that is, the rule that prohibits the admission of evidence that the plaintiff has sought or received compensation from someone other than the defendant). ${ }^{67}$ Studies less frequently have tested other reforms, such as split recovery (requiring plaintiffs to split a part of their punitive damages awards with the general public), ${ }^{68}$ and the introduction of

60 L-M Baldwin et al, Defensive Medicine and Obstetrics (1995) 274 JAMA 1606; FA Sloan et al, Tort Liability and Obstetricians' Care Levels (1997) 17 International Review of Law and Economics (IRLE) 245.

61

62

63

64 Encinosa/FJ Hellinger, Have State Caps on Malpractice Awards Increased the Supply of Physicians? (2005) W5 Health Aff 250; Kessler/Sage/Becker (2005) 293 JAMA 2618.

65 J Currie/WB MacLeod, First Do No Harm? Tort Reform and Birth Outcomes (2008) 123 The Quarterly Journal of Economics (QJE) 795.

66 See eg Encinosa/Hellinger (2005) W5 Health Aff 250.

67 See eg Currie/MacLeod (2008) 123 QJE 795; ER Carrier et al, Physicians' Fears Of Malpractice Lawsuits Are Not Assuaged By Tort Reforms (2010) 31 Health Aff 1585.

68 Carrier et al (2010) 31 Health Aff 1585. 
no-fault victims' compensation funds. ${ }^{69}$ There are also studies that have grouped together various types of damages caps, ${ }^{70}$ but this prevents testing which has the largest effect. ${ }^{71}$

Tort reforms can be a robust measure of liability risk when used in difference-in-differences research. ${ }^{72}$ Empirical studies that have used tort reforms as a measure systematically demonstrate that tort reforms have no or little effect on physician behaviour. This finding applies to essentially all outcome measures (dependent variables). Consequently, the evidence as to whether tort reforms impact on physician behaviour is weak at best.

Malpractice insurance premiums have also been used as an independent variable. The underlying assumption of using malpractice insurance premiums as an independent variable is that insurance premiums reflect malpractice risk. However, it has been claimed, and sometimes found, that the relationship between insurance premiums and malpractice claims is weak, ${ }^{73}$ that the increase in medical insurance premiums is higher than the increase in liability payouts by insurers, ${ }^{74}$ and that the increase in malpractice payments is not the driving force behind increases of malpractice insurance premiums. ${ }^{75}$ This makes it the use of medical insurance premiums as a dependent variable questionable. ${ }^{76}$

\section{B Self-reporting versus actual practice research}

Studies have also analysed the effect of liability on self-reported physicians' professional responses other than the services they actually offer to their patients. Such responses, which are generally measured by means of a questionnaire, include stopping seeing certain patients, considering early retirement, limiting the scope of their practices, dissatisfaction with their profession, an increase of stress, devoting less time to routine visits, and discouraging their

69 Klick/Stratmann (2007) 36 JLS s121; Carrier et al (2010) 31 Health Aff 1585.

70 Matsa (2007) 36 JLS (comparing damage caps to other tort reforms); D Kessler/M McClellan, Do Doctors Practice Defensive Medicine? (1996) 111 QJE 353.

71 Yang et al (2008) 5 JELS 21, 26.

72 A limitation is that statistical techniques related to difference-in-differences approaches often have validity concerns because they may lead to overestimation of significance levels: see ibid, 28; Eisenberg (fn 19).

73 Black et al (2005) 2 JELS 207.

74 Americans for Insurance Reform, Medical Malpractice Insurance: Stable Losses/Unstable Rates (2007).

75 Baicker/Chandra (2005) 8 FHEP 1 or (2005) 28 Regulation 24 (finding that increases in malpractice payments to patients did not seem to be the driving force behind increases in malpractice insurance premiums). See also $D A$ Conrad et al, Malpractice Premiums in 1992: Results of a National Survey of Dentists (1995) 126 Journal of the American Dental Association (JADA) 1045 (identifying a number of factors that influence dentists' insurance premiums, including the number of previous complaints or claims, whether dentists owned their practice, the number of lawyers in the area/state, and the extent of water fluoridation).

76 Studies that use malpractice insurance premiums as a dependent variable suffer from the fact that what caused the tort reform may also have caused the increase or decrease of malpractice premiums (spuriousness), see Eisenberg (fn 19) 16 (also claiming that a study that takes this into account did not find an effect). 
children from entering medicine. ${ }^{77}$ While these studies often find that liability risk has an effect on physicians' professional reactions, a problem with survey research is that the inquiry is aimed at measuring perceptions (that is, the perception of whether physicians practice defensive medicine as a result of liability risk), and that what people say often deviates from what they do, particularly when it concerns accounts of mental processes. ${ }^{78}$ Evidence for this discrepancy has repeatedly been found in a medical malpractice context. For example, Mello et al (2007), who collected and compared survey data and real life information, found that only $3 \%$ of specialists had actually restricted their practice during a certain period, while $43 \%$ of the specialists said they did. ${ }^{79}$ Similarly, the famous Harvard Medical Study revealed that the overall perceived risk of being sued in a given year was approximately three times the actual risk of being sued. ${ }^{80}$ Additionally, the study found that, even though physicians believed they practiced defensive medicine, they did not report long-term changes in their practice patterns as a result of a specific suit, ${ }^{81}$ which could imply that physicians may attribute a perceived threat to liability risk while it actually has other causes (for example, increased expectations from society with respect to what physicians are capable of, less willingness of the society to accept a medical error). More recent actual practice research compared their outcomes with previous survey results and also reported striking differences. ${ }^{82}$

Other limitations of physician surveys are that physicians who have experienced a claim may be more likely to respond or participate in a study, ${ }^{83}$ or may overstate malpractice threats or have other misperceptions about the risks of malpractice claims. ${ }^{84}$ Physicians may also respond to survey questions with politically correct answers, or respond to survey questions in a socially desirable way - for the public - by explaining their actions and motives based on purely clinical

77 SC Charles/JR Wilbert/KJ Franke, Sued and Nonsued Physicians' Self-Reported Reactions to Malpractice Litigation (1985) 142 The American Journal of Psychiatry (Am J Psychiatry) 437; RS Shapiro et al, A Survey of Sued and Nonsued Physicians and Suing Patients (1989) 149 Archives of Internal Medicine (Arch Intern Med) 2190; Martin et al (1991) 84 SMJ 1300; Levinson et al (1997) 277 JAMA 553; Mello et al (2007) 26 Health Aff 425; Sobel/Loughlin/Coogan (2006) 175 J Urol 1847.

78 RE Nisbett/TD Wilson, Telling More than We Can Know: Verbal Reports on Mental Processes (1977) 84 Psychological Review (Phys Rev) 231.

79 MM Mello et al, Changes In Physician Supply And Scope Of Practice During A Malpractice Crisis: Evidence from Pennsylvania (2007) 26 Health Aff 425.

80 Harvard Medical Practice Study (fn 49).

81 Ibid.

82 Waxman et al (2014) 371 NEJM 1518.

83 Mello et al (2007) 26 Health Aff 425, 433.

84 Carrier et al (2010) 31 Health Aff 1585; AG Lawthers et al, Physicians' Perceptions of the Risk of Being Sued (1992) 17 Journal of Health Politics, Policy and Law (JHPPL) 463; JF Dick III et al, Predictors of Radiologists' Perceived Risk of Malpractice Lawsuits in Breast Imaging (2009) 192 American Journal of Roentgenology (AJR) 327. 
grounds. ${ }^{85}$ This makes physician surveys unreliable for accurately measuring defensive medicine.

The validity concerns that come with self-reporting may explain why survey research shows more and larger effects than research that analyses files or existing databases (actual practice research). ${ }^{86}$ Actual practice research rarely finds statistically significant effects, even if research is based on a large number of observations (for example, over 10,000 files). If such studies do find an effect, this is generally small. This trend particularly applies to more recent studies. For instance, Yang et al (2008) found no effects of malpractice premiums on physician supply, while Dubay et al (1999 and 2001) found small effects of higher malpractice premiums on the increase in the incidence of late prenatal care, on the total number of prenatal care visits (lower) and on C-sections and infant health. ${ }^{87}$ In contrast, a Reed et al (2008) survey found that physicians with higher levels on the Malpractice Fear Scale were more likely to report changes in their teaching behaviour due to malpractice fear than physicians with lower scores (rho $=0.38, \mathrm{p}<.001) .{ }^{88}$ Additionally, Martin et al (1991), surveying sued and non-sued physicians, found that stress was increased among physicians with cases pending or multiple previous suits. ${ }^{89}$

However, database accuracy can be an issue in actual practice research. The National Practitioner Data Bank (NPDB), which is frequently used in medical malpractice research, has been said to be incomplete, for example because hospitals shield claims from the database. ${ }^{90}$ More generally, it has been argued that datasets can lack important data, for example information about previous lawsuits against physicians, ${ }^{91}$ data on self-insured physicians (especially in large hospitals), ${ }^{92}$ or information on physicians' awareness of tort reforms. ${ }^{93}$ Doubts may be raised regarding studies that rely on information from such databases, but is not known whether this concern affects existing results.

85 USC Office of Technology Assessment (fn 55) 4.

86 See also Eisenberg (fn 19), referring to Mello et al (2007) 26 Health Aff 425.

87 Yang et al (2008) 5 JELS 21; Dubay/Kaestner/Waidmann (2001) 20 J Health Econ 591; Dubay/Kaestner/Waidmann (1999) 18 J Health Econ 491.

88

89

90

TM Waters et al, The Role of the National Practitioner Data Bank in the Credentialing Process (2006) 21 American Journal of Medical Quality (AJMQ) 30, 31 (providing further references).

91 For example, HS Brown, Lawsuit Activity, Defensive Medicine, and Small Area Variation: The Case of Cesarean Sections Revisited (2007) 2 Health Economics, Policy and Law (HEPL) 285.

92 Thomas/Ziller/Thayer (2010) 29 Health Aff 1578.

93 Carrier et al (2010) 31 Health Aff 1585. 


\section{Causal explanations}

The inability to conduct real-life experiments imposes limitations on the making of causal inferences. ${ }^{94}$ It is important to take these into consideration when evaluating existing empirical research. The most problematic studies, at least from a causality point of view, are studies that lack a comparison group. For example, one study asked urologists in the US about the impact of the current medical malpractice environment. ${ }^{95}$ Respondents indicated that they were considering referring difficult cases (58\%), limiting their practice's scope $(60 \%)$, relocating to a different state $(41 \%)$, and leaving the practice of medicine (41\%). The problem here is that it may be that respondents in a comparison group (for example, physicians who never suffer from liability) would report similar percentages.

A relationship (correlation) can only be considered causal if there is a clear temporal order between the measures (variables) that are used and if the relationship is not spurious. Several studies lack a clear temporal order, which casts doubts on whether defensive medicine is the result of legal claims or whether legal claims are the result of defensive medicine. For example, one study found that patients who were treated by physicians with a malpractice history compared to physicians with no or less malpractice history were more likely to complain because they felt rushed, never received explanations for tests, or felt ignored. ${ }^{96}$ Intuitively, one might ascribe these effects to liability, but the explanation can go both ways. Legal claims may impact on how physicians perceive their patients and cause them to communicate less openly with them, but it could also be that poor communication causes patients to file claims against their physician, or that physicians who make their patients feel rushed are more likely to be involved in a malpractice claim than physicians who do not rush their patients or do so to a lesser extent.

Additionally, spurious relationships is sometimes an issue in existing studies. ${ }^{97}$ A real life example of spuriousness is the relationship between doctor visits and death. In this case, there is a relationship, but it is not causal (that is, people do not die because of a doctor visit). Instead, illnesses explain both the number of doctor visits and the number of patients that decease. People

94 This is not to criticise the studies that have been done. Researchers often encounter limitations as to the data they can obtain.

95 Sobel/Loughlin/Coogan (2006) J Urol 1847. The questionnaire included questions about past experience with tort claims.

96 GB Hickson et al, Obstetricians' Prior Malpractice Experience and Patients' Satisfaction With Care (1994) 272 JAMA 1583.

97 For example, Dubay/Kaestner/Waidmann (1999) $18 \mathrm{~J}$ Health Econ 491, referring to AR Localio et al, Relationship Between Malpractice Claims and Cesarean Delivery (1993) 269 JAMA 366 and AD Tussing/MA Wojtowycz, The Cesarean Decision in New York State, 1986. Economic and Noneconomic Aspects (1992) 30 Med Care 529. See also Eisenberg (fn 19) 21 (claiming that '[s]tudies that find an association between liability pressure and increased rates [sc of malpractice pressure] tend to use aggregated premium pressure or tort reform statutes, and no control group of physicians removed from liability pressure. They are less persuasive than studies using individualized pressure and control groups'). 
who are ill visit the doctor more often and are more likely to die. Spuriousness in a defensive medicine context entails that a study cannot rule out that both defensive medicine and liability result from a third event or circumstance. ${ }^{98}$ Increased societal demands regarding the appropriate level of care could be a factor in medical malpractice research similar to illness in the real life example. Societal demands may explain why patients file claims as well as why physicians are or have become careful practising medicine. Similarly, technological advances may make it easier to diagnose and identify physicians' mistakes as well as making it easier to establish and prove a legal claim, and consequently holding physicians liable. Correspondingly, a better review of physicians' activities may result in fewer claims and in physicians being less concerned with liability. Clearer guidelines on how to treat patients may make it easier to determine liability and may cause more physicians to order more tests or different tests.

One study in particular illustrates how a common cause may contaminate the relationship between tort liability and defensive medicine because both the cause (that is, tort liability) and the effect (namely, defensive medicine) are the result of a third variable (the common cause). The study examined whether physicians' fear of litigation was associated with defensive practices. ${ }^{99}$ It was found that their exists a relationship between the fear of malpractice litigation and defensive practice. Additionally, the findings revealed that stress from uncertainty correlated both with fear of malpractice litigation and with defensive practices. This result suggests that stress from uncertainty may be a common cause of both malpractice fear and defensive medicine, which becomes a problem if the physicians who experienced a malpractice claim initially differ in stress levels than physicians who did not experience a malpractice claim. Since spurious relationships are difficult to avoid in non-randomised trials, most studies find correlations (that is, that effects that do not necessarily have to be causal) rather than causal relationships. Randomised trials are preferred when testing causal relationships, because they allow researchers to randomly assign subjects (for example, physicians) to groups (such as a group where the subjects experience a malpractice claim and a group where they do not experience such a claim). The randomisation is the best available strategy to rule out initial differences between the groups that are tested. As a result, differences between the groups will be attributable to the intervention (for example, being exposed to a malpractice claim). However, randomised trials are extremely difficult to conduct in a real-life setting. For example, it is impossible (or highly unethical) to randomly assign physicians to groups where they will or will not be exposed to a malpractice claim.

The difficulty to establish a causal relationship in non-randomised settings explains why many studies use tort reforms as a measure of liability risk. It is difficult to come up with events

98 The examples below are reported in Harvard Medical Practice Study (fn 49).

99 J Benbassat/D Pilpel/R Schor, Physicians' Attitudes Toward Litigation and Defensive Practice: Development of a Scale (2001) 27 Behavioral Medicine (Behav Med) 52. 
or circumstances that could confound the relationship between liability (that is, tort reforms) and defensive practices. ${ }^{100}$ This makes tort reforms a seemingly robust measure of liability risk. The idea here is that comparing, for example, physician supply before and after a tort reform (for example, the introduction of damage caps), and/ or comparing physician supply in US states with and without liability protection provides an indication of whether a certain liability regime impacts on the number of physicians. ${ }^{101}$

\section{Synthesis}

Only selecting actual practice research that includes a control group and that measures either the effect of tort reforms on physician services or the effect of claims history (that is, individual physicians' involvement in malpractice claims) on physician services results in a limited number studies that remain. The outcomes of these studies suggest that the evidence for defensive medicine is weak at best. This applies for both studies using tort reforms ${ }^{102}$ as a measure of liability risk and research that uses claims history. ${ }^{103}$

\section{Conclusion}

Should actors in the medical field, and possibly in other fields, fear legal claims? The answer: we do not know for sure, but probably not. At face value, empirical studies provide mixed results. However, a further inspection reveals that not all measures seem suitable for analysing defensive medicine. This applies to malpractice insurance premiums (not necessarily related to malpractice claims and malpractice payments), physician supply (extreme result, possible database accuracy issues), research that lacks a comparison group (causality concerns) and studies that rely on selfreporting (measurement concerns). Disregarding studies that lack a control group, use insurance premium measures as a defensive medicine measure, and studies that rely on self-reporting

100 This is clearly not a given. If the effect of tort reforms is examined in a period of malpractice crisis, different effects may be found compared to when there is no malpractice crisis.

101 Still, the issues remain database accuracy and whether the measures adopted (eg physician supply) are measures of defensive medicine.

102 Waxman et al (2014) 371 NEJM 1518 (reporting 'little (if any) change').

${ }^{103}$ D Dranove/Y Watanabe, Influence and Deterrence: How Obstetricians Respond to Litigation Against Themselves and Their Colleagues (2010) 12 American Law and Economics Review (ALER) 69 (examining whether physicians perform more cesareans after they or their colleagues have been contacted about a lawsuit, finding 'very small, short-lived increases in cesarean section rates', and concluding that '[i]t does not appear that the recent sharp rise in cesarean section rates is in direct response to litigation'); GW Gimm, The Impact of Malpractice Liability Claims on Obstetrical Practice Patterns (2010) 45 Health Services Research (HSR) 195 (reporting lower physician delivery volume as a result of malpractice claims, but no significant impact on Csection rates); $D$ Grant/MM McInnes, Malpractice Experience and the Incidence of Cesarean Delivery: A Physician-Level Longitudinal Analysis (2004) 41 Inquiry 170 (finding that physicians experiencing malpractice claims increase cesarean rates by approximately one percentage point); Baldwin et al (1995) 274 JAMA 1606 (finding no effect on cesarean section rates). 
dramatically narrows down the number of empirical studies. The remaining studies demonstrate that liability effects are small at best. The idea that physicians do not or hardly ever practise defensive medicine is consistent with empirical research focusing on psychiatrists, ${ }^{104}$ firemen, ${ }^{105}$ the police, ${ }^{106}$ and financial regulators. ${ }^{107}$ Studies in those fields have also shown small or no effects resulting from tortious liability. ${ }^{108}$

An interesting observation is that survey research does tend to produce evidence of the practice of defensive medicine. This suggests that defensive medicine merely or predominantly exists in the minds of people. Consequently, the belief physicians have with respect to medical malpractice is not necessarily related to the actual number of claims or the actual malpractice risk. This suggests there may not be a need to call for legal reforms, at least not to tackle defensive medicine issues. Perhaps it would be more meaningful to look into possibilities to change physicians' perceptions about tort liability exposure and its effects.

Acknowledgment: I would like to thank the anonymous reviewer(s) and Eric Tjong Tjin Tai for their comments and suggestions, and Thomas van Alphen for his research assistance.

104 Givelber/Bowers/Blitch (1984) WLR 443 (suggesting that the prediction that the Tarasoff decision would discourage treatment of dangerous patients was exaggerated).

105 Hartshorne/Smith/Everton (2000) 63 MLR 502 (finding that 'liability has not led to widespread defensive firefighting, has had little implication for resource allocation or insurance arrangements, and may in fact have led to an increase in the standard of care').

${ }^{106}$ FA Van Tilburg, Effecten van civielrechtelijke aansprakelijkheid op openbare-ordebeleid: Empirisch onderzoek naar de invloed van civielrechtelijke aansprakelijkheid op het beleid van de burgemeester en politie als handhavers van de openbare orde (dissertation Tilburg 2012) (finding no evidence for an effect of liability on decisions regarding maintaining the public order in the Netherlands).

107 J Trebus/G van Dijck, Effecten van aansprakelijkheid op het handelen van de AFM empirisch onderzocht (2014) 14 Aansprakelijkheid, Verzekering \& Schade (AV\&S) 99.

108 For an exception, see Horwitz/Mead (2009) 6 JELS 585 (claiming a large correlation between tort liability immunity and volunteer rates in the US). 